\title{
PENNSYLVANIA RULES GOVERNING THE ALLOCATION OF RECEIPTS DERIVED BY TRUSTEES FROM SHARES OF STOCK
}

\section{ROBERT BRIGHAM $\dagger$}

The never-ending conflict between life beneficiary and remainderman over receipts from shares of corporate stock is a perennial source of discussion. For eighty years the Supreme Court of Pennsylvania has held, and still holds, a position of leadership in this field of the law. ${ }^{1}$ During that period, and particularly within the last ten years under the leadership of Mr. Chief Justice Kephart, it has refined its general rules by establishing a large body of principles by which the objectives of the general rules are to be attained in particular cases. Although the application of the general rules never has been, and never will be, easy, this process of refinement has been of real help in mitigating the difficulty of application which is the chief argument of those who would establish easy, but arbitrary, rules.

The general Pennsylvania rules are, of course, known to all. They are rules of property, ${ }^{2}$ and, therefore, they can be changed only by the legislature. $^{3}$ To debate their desirability or undesirability would be merely to rattle old bones. To plunge into a maze of arithmetic would be tiresome and unprofitable.

However, the refinements introduced by the recent decisions are as elusive as they are helpful in a particular case. The supreme court has itself, in Waterhouse's Estate, ${ }^{4}$ summarized many of them. Since that decision there have been further developments and, moreover, the limitations of a single opinion necessarily prevented a discussion of all phases of the subject. For these reasons it seems not out of place at this time to correlate the familiar general rules with the less familiar principles governing their application, avoiding purely academic discussion on the one hand and tedious arithmetic on the other.

$\dagger$ B. A., I921, Yale; LL. B., I929, University of Pennsylvania; member of the Philadelphia Bar.

I. The rules originally established by that court are the basis of RESTATEMENT, TRUSTS (I935) § 236, and are known as the "Pennsylvania" or "American" rules. The Restatement, however, denies the right of the life beneficiary to participate in certain cases where, as wiil be pointed out, the Supreme Court of Pennsylvania now accords him that right.

2. Maris's Estate, 301 Pa. 20, 24, I5I Atl. 577, 578 (I930); Harkness's Estate, 283 Pa. $464,466,467$, I29 At1. 458, 459 (I925).

3. Stokes' Estate (No. I), $240 \mathrm{~Pa}$. 277, 282, 87 At1. 97I, 973 (I913). Consequently, the Pennsylvania courts cannot be expected to follow the Restatement in cases where the latter is not in accord with the Pennsylvania decisions. See the statement of Mr. Chief Justice Kephart before the American Law Institute on May 5, r933. II Proc. AMr. L. INST. I96-200 (I933).

4. 308 Pa. 422, I62 Atl. 295 (I932). 
Assuming that the trust is one to which the general Pennsylvania rules of apportionment apply, ${ }^{5}$ it makes no difference that the estate is still in the hands of the executor and has not yet been awarded to the trustee, ${ }^{6}$ nor is it material whether the gift to the remaindermen is specific, demonstrative or general. ${ }^{7}$ In applying the rules the court will tend to favor the life beneficiaries, at least when they are the widow and children of the creator of the trust, ${ }^{8}$ for whom he might be expected to have more regard than for unborn or unascertained remaindermen. And in no event will the rights of the life beneficiaries be affected by the decisions of the federal courts in income tax cases, ${ }^{9}$ or by the accounting requirements of the Interstate Commerce Commission, ${ }^{10}$ or by the provisions of the National Banking Act prohibiting stock dividends. ${ }^{11}$

Even the intention of the creator of the trust is subject to limitations. That intent, if expressed, will govern so far as it is legal. ${ }^{12}$ Although the creator of the trust may give the life beneficiary more than the application of the Pennsylvania rules would give him, ${ }^{13}$ he cannot give the life beneficiary less. A direction to keep in corpus what would normally be awarded as income is subject to the statute against accumulations and will be stricken down, ${ }^{14}$ unless the particular accumulation is authorized by that statute.

5. They may not apply at all where a testator who died prior to June 7 , r9I7, created a legal life estate, rather than a trust, in shares of stock. In such a case, the life beneficiary must enter security for the protection of the remaindermen unless the will stipulated to the contrary. PA. Stat. ANn. (Purdon, 1930) tit. 20, \$2770; Act of May I7, I87I, P. L. 269, \$ I. On the entry of security, the life beneficiary became the absolute owner of the shares and was merely the debtor of the remaindermen for their value. The life beneficiary in such a case is absolutely entitled to any dividends or profits that might be realized. Letterle's Estate, 248 Pa. 95, 93 Atl. 935 (I9I5) ; Kirkpatrick's Estate, 284 Pa. 583, I3I Atl. 36I (I925). If the life beneficiary, being required to enter security, did not do so, the court would appoint a trustee to hold the property. If such appointment was made upon petition of the life beneficiary alone, the result is the same as though security had been entered. Weir's Estate, 25I $\mathrm{Pa}$. 499, 96 Atl. I086 (r9I6). In such a case all dividends and profits would apparently belong to the life beneficiary and no question of apportionment would arise. If, however, both life beneficiary and remaindermen joined in the application for the appointment of a trustee, the shares would be held in trust for all purposes, just as though the testator had himself created the trust. Loewer's Estate, $263 \mathrm{~Pa}$. 517, I06 Atl. 789 (I9I9). See Veech's Estate, $74 \mathrm{~Pa}$. Super. 373 (I920), in which court and counsel treated the trust as though it had been created by the testator. This question probably would not arise where the testator died on or after June 7, r917. Such a trust would be governed by $\$ 23$ of the Fiduciaries Act, effective that date. PA. STAT. ANN. (Purdon, 1930) tit. 20, $\$ 635$. The ordinary rules of apportionment would probably apply to a trust set up under the provisions of that act, although it should be noted that the trustee would have no authority to retain shares of corporate stock.

6. Flinn's Estate, 310 Pa. 206, 211, I65 Atl. 3I, 33 (I932).

7. Flaccus's Estate, $283 \mathrm{~Pa}$. I85, I29 At1. 74 (I925).

8. Opperman's Estate (No. I), 3I9 Pa. 455, 459, I79 Atl. 729, 732 (I935).

9. Harkness's Estate, 283 Pa. 464, I29 At1. 458 (r925).

Io. Cassatt's Estate, I05 Pa. Super. I4, I58 At1. 586 (r932).

Ir. Thompson's Estate, 262 Pa. 278, 280 , I05 Atl. 273, 274 (I918).

I2. Jones v. Integrity Trust Co., $292 \mathrm{~Pa}$. I49, I56, I40 At1. 862, 864 (I928); RestateMENT, TRUSTS (I935) $\$ 236$, comment $b$.

I3. E. g., Robinson's Trust, 218 Pa. 48ז, 67 Atl. 775 (1907).

I4. Maris's Estate, 30I Pa. 20, I5I Atl. 577 (I930). Contra: Equitable Trust Co. v. Prentice, 250 N. Y. r, 164 N. E. 723 (1928). See Note (r93I) 79 U. of PA. L. REv. 336. The Pennsylvania statute prohibiting accumulations is found in PA. STAT. ANN. (Purdon, I930) tit. 20, § 3251. 
The occasion for an apportionment may be furnished either by an act of the corporation whose shares are held by the trustee or by an act taking place wholly within the trust estate. The corporation may declare a dividend or issue rights to subscribe to additional shares, or it may go into total or partial liquidation or merge with another corporation. Even though the corporation has done nothing, an apportionment may become necessary because the trustee has sold the shares at a profit. However, unless there is some act, either by the corporation or within the trust estate, there is no occasion for an apportionment so long as the trustee merely continues to hold the shares. ${ }^{15}$

Although the general rules differ in certain important respects, principally as to the burden of proof, depending upon the particular occasion which makes an apportionment necessary, the object of the Pennsylvania rule is to give the life beneficiary all earnings which have been accumulated by the corporation during the period when the shares were held in the trust, provided that the intact value of the investment is not thereby impaired. These two concepts, namely, intact value and earnings, are encountered in every apportionment, and it is in their development that the recent decisions assume such great importance. ${ }^{16}$ A thorough analysis of these concepts will make it possible to treat very briefly the more familiar general rules which determine when the life beneficiary is, and when he is not, entitled to an apportionment.

In order to simplify the discussion as much as possible, the rules will be stated in terms of a testamentary trust, although the same rules apply to a trust created by deed or declaration. We shall therefore speak of the creator of the trust simply as "the testator", which term should also be understood to include a settlor of an inter vivos trust. Again, the period during which the shares were held in the trust may commence with the death of the testator or execution of the trust instrument, if the shares were received from the creator of the trust, or it may commence with the subsequent acquisition of the shares by the trustee, as the case may be. In order to avoid frequent repetition of this enumeration, the commencement of this period will be referred to simply as the death of the testator, which term should be understood to include the others. Finally, the person entitled to the income of the estate will be referred to as the "life beneficiary", although he may in fact be a tenant for years or a tenant pur autre vie.

I5. Buist's Estate, 297 Pa. 537, 543, I47 Atl. 606, 608 (I929); Nirdlinger's Estate, 290 Pa. 457, 477, 479, I39 Afl. 200, 208 (I927); cf. Restatement, TrUSts (I935) $\$ 236$ (e) and comment $y$.

I6. It is at this point, also, that one gets little or no help from REsTatement, TRUSTs, $\$ 236$, and the comments thereto, or from most of the vast amount of discussion which has been devoted to this field of law. 


\section{The Determination of Intact Value}

The term intact value has been defined as that value which must be preserved for corpus. ${ }^{17}$ Until very recently there was a great deal of doubt as to the determination of that value. Although some of the earlier cases used the market value of the shares, ${ }^{18}$ and others said that market value may aid in the determination, ${ }^{19}$ it is now settled that intact value is not market value. $^{20}$ Likewise, it is now settled that neither appraised nor inventory value, although formerly used, ${ }^{21}$ is the intact value. ${ }^{22}$ Other earlier cases have mentioned "actual", "real", or "intrinsic" value. ${ }^{23}$

At present most of this confusion has been set definitely at rest. Prima facie, intact value is the "book value" of the shares, ${ }^{24}$ calculated as of the date either of the testator's death, ${ }^{25}$ if he owned the shares, or of their acquisition by the trustees ${ }^{26}$ if acquired in any manner other than by purchase. Where different lots of shares were acquired at different times, the intact value is prima facie the sum of the intact values of each lot calculated as of the date of its acquisition. ${ }^{27}$

Book value is, of course, merely the value which each share is shown to have at that time by the books of the corporation. Generally speaking, that value is the par value plus earnings accumulated up to that time. ${ }^{28}$ More simply stated, it is the capital and surplus divided by the number of shares outstanding at that date. ${ }^{29}$

However, there is an inconsistency which has crept into the recent cases. If the trustee acquired the shares from the testator, their book value

17. Waterhouse's Estate, 308 Pa. 422, 427, I62 At1. 295, 296 (1932).

18. Philadelphia Trust, Safe-Deposit \& Ins. Co.'s Appeal, 24 W. N. Cas. 137, 16 Atl. 734 (Pa. I889) ; Earp's Appeal, 28 Pa. 368 (I857).

19. Stokes' Estate (No. 2), 240 Pa. 288, 291, 87 Atl. 975, 976 (Igr3) ; Boyer's Appeal, 224 Pa. I44, I52, 73 Atl. 320, 322 (I909) ; Smith's Estate, I40 Pa. 344, 357, 21 Atl. 438, 440 (ISgI).

20. Baird's Estate, $299 \mathrm{~Pa} .39,42$, I48 Atl. 907, 908 (1930) ; Jones v. Integrity Trust Co., 292 Pa. 149, I55, I40 At1. 862, 864 (I928) ; Packer's Estate (No. I), 291 Pa. 194, 196, I39 At1. 867 (I927) ; Dickinson's Estate, 285 Pa. 449, 455, I32 At1. 352, 353 (I926).

2I. Mandeville's Estate, 286 Pa. 368, I33 Atl. 562 (I926) ; Quay's Estate, 253 Pa. 8o, 97 Atl. I029 (I9I6).

22. Flinn's Estate, 310 Pa. 206, 209, I65 At1. 31, 32 (I932).

23. Dickinson's Estate, $285 \mathrm{~Pa}$. at 455, I32 Atl. at 353; Waterman's Estate, $279 \mathrm{~Pa}$. 49I, 496, 124 Atl. 166, I68 (I924) ; Boyer's Appeal, 224 Pa. at I52, 73 Atl. at 322; Smith's Estate, r $40 \mathrm{~Pa}$. at 357, 2I Atl. at 440; Philadelphia Trust, Safe Deposit and Insurance Company's Appeal, 24 W. N. Cas. I37, I6 Atl. 734; Moss's Appeal, 83 Pa. 264, 27I (I877).

24. Waterhouse's Estate, $308 \mathrm{~Pa}$. at 427, I62 Atl. at 296; Baird's Estate, $299 \mathrm{~Pa}$. at 42 , I48 Atl. at 908. See also Dickinson's Estate, 285 Pa. 449, I32 Atl. 352; Mallory's Estate, 285 Pa. I86, I3I Atl. 7I4 (I926) ; McKeown's Estate, 263 Pa. 78, I06 At1. I89 (I9I9); Thompson's Estate, $262 \mathrm{~Pa} .278$, $105 \mathrm{Atl} .273$ (IgI8), for earlier cases in which book value was used. at 908 .

25. Flinn's Estate, 310 Pa. at 2I0, I65 At1. at 32; Baird's Estate, $299 \mathrm{~Pa}$. at 42, I48 Atl.

26. Flinn's Estate, 310 $\mathrm{Pa}$. at $2 \mathrm{rr}, \mathrm{I} 65$ At1. at 33 (shares received from another corporation and later sold at a profit) ; Bullitt's Estate, 308 Pa. 4I3, I62 Atl. 288 (I932) (shares donated by life beneficiaries).

27. Jones v. Integrity Trust Co., $292 \mathrm{~Pa}$. at I52, I40 Atl. at 863 .

28. Waterhouse's Estate, $308 \mathrm{~Pa}$. at 427, I62 At1. at 296; Nirdlinger's Estate, $290 \mathrm{~Pa}$. at 464, r39 Atl. at 203.

29. Mallory's Estate, 285 Pa. at I9r, I3I Atl. at 7I5. 
is prima facie their intact value. ${ }^{30}$ If, on the other hand, the trustee purchased the shares, the cases indicate that the purchase price, and not the book value at the date of purchase, is the intact value. ${ }^{31}$ The purchase price is of course merely the market value and therefore, in this one instance, intact values are actually determined by market values, in spite of the reiterated statements that market value has nothing to do with intact value. ${ }^{32}$ Perhaps this result, although logically inconsistent, does substantial justice, because the trustee has actually paid out money and because this expenditure should be preserved for the remaindermen. Otherwise, it might not be preserved if, as is frequently the case, the shares were purchased at a price in excess of their book value.

In calculating the book value in order to make a prima facie determination of intact value, it usually happens that the testator's death did not coincide with the termination of an accounting year of the corporation. When the testator dies in the middle of an accounting year, it is usually impossible to secure a balance sheet as of the day of the testator's death. For this reason it has been customary to calculate the surplus on the testator's death by averaging the earnings of the corporation for that year on a per day basis and adding the amount thus obtained to the surplus shown by the last balance sheet prior to the testator's death. This practice has been sanctioned recently by the supreme court. ${ }^{33}$ It should not be followed, however, except in cases of necessity, for "averaging is not allowed when definite figures can be obtained". ${ }^{34}$

As has been noted, the book value is not conclusive as to the intact value. Nevertheless, the corporate books are presumed to have been kept in good faith, ${ }^{35}$ and the burden of proof rests upon the person asserting a higher or lower value than that shown by the books. ${ }^{36}$ The evidence must be of a character to leave no doubt that a mistake has been made, or that fraud has been committed. ${ }^{37}$ Although a general reappraisal of the assets of the corporation will not be permitted, ${ }^{38}$ the real values of assets carried at nominal amounts may be shown. ${ }^{39}$ If the corporation is a mining or other "wasting assets corporation", the necessity of proving that adequate reserves for depletion were maintained depends on who has the burden of proof. If the remaindermen must prove an impairment of intact value, it

30. See cases collected supra notes 24 and 25.

31. Hostetter's Trust, 319 Pa. 572, I8I Atl. 567 (I935) ; Jones v. Integrity Trust Co., 292 $\mathrm{Pa}$. at I 53, 140 Atl. at 864 :

32. See cases collected sippra note 20 .

33. Flinn's Estate, 3 10 Pa. at 212, I65 Atl. at 33.

34. Jones v. Integrity Trust Co., $292 \mathrm{~Pa}$. at 152 , 140 At1. at 863.

35. Baird's Estate, $299 \mathrm{~Pa}$. at $42,148 \mathrm{Atl}$. at 908.

36. Waterhouse's Estate, $308 \mathrm{~Pa}$. at 428, 162 Atl. at 296; Baird's Estate, $299 \mathrm{~Pa}$. at 42, I48 Atl. at 908.

37. Baird's Estate, $299 \mathrm{~Pa}$. at 42, I48 Atl. at 908.

38. Waterman's Estate, 279 Pa. at 496, I24 At1. at 167.

39. Baird's Estate, 299 Pa. at 43, I48 Atl. at 909. 
will be presumed that the reserves are adequate, unless the contrary is shown; but if the life beneficiary must prove that intact value is not impaired, he should offer affirmative evidence as to reserves for depletion. ${ }^{40}$

Corporations frequently make changes on their books in order to correct previous entries. If in the interim the testator died, the books, as they existed at his death, would not present a correct picture. Where the corporation recognizes this by a later change in the books, the intact value should be corrected. Thus, where the corporation, after the testator's death, restores excess depreciation that has been charged off in previous years, such excess depreciation up to the death of the testator may be added to the intact value. ${ }^{41}$ On the other hand, where the corporation writes off an item of "good will" prior to the testator's death and restores it thereafter, the court has refused to allow the restored "good will" to be added to the intact value of the shares. ${ }^{42}$ The latter result was caused by the fact that the court apparently regarded the item "good will" as having been at all times fictitious, at least in the case then before it.

Another type of correction of intact value may be made necessary by a condition which, although existing at the death of the testator, does not manifest itself upon the books of the corporation until a later date. For example, the corporation was engaged, at the testator's death, in performing a large contract but did not then carry the contract as an asset on its books because it was uncertain whether it would ultimately result in a profit or a loss. In fact it resulted in a large profit. The court held that this profit must be added to the book value of the shares as of the testator's death in order to ascertain the intact value. ${ }^{48}$ If the contract had resulted in a loss, the amount thereof would have been subtracted. ${ }^{44}$ It is believed that this case presents an unusual situation by reason of the extraordinary size of the contract involved. If this case announces a rule of general application, the door is thrown open to an analysis of a myriad of ordinary transactions, started before the death of the testator, in order to determine whether they resulted in profits or losses thereafter. Such a result would place an intolerable burden upon the person who had the burden of proving what the intact value was.

Changes in intact value may also be made necessary by reason of events occurring subsequent to the death of the testator. These may be either (I) events which occur within the corporation or (2) events which

40. Compare Harkness's Estate, 5 D. \& C. 35I, 352, 353 (Orph. Ct. Phila. 1924), aff'd on other points, $283 \mathrm{~Pa}$. 464, I29 Atl. 458 (I925), in which the burden was on the remainderman, with McKeown's Estate, $263 \mathrm{~Pa}$. 78, 83, I06 At1. I89, I90 (I9I9), in which the life beneficiaries produced affirmative evidence. Cf. REsTATEMENT, TRUSTs, $\$ 236$, comment $z$.

4I. Baird's Estate, $299 \mathrm{~Pa}$. at 44, I48 Atl. at 909.

42. Baird's Estate, $299 \mathrm{~Pa}$. at 43, I48 Atl. at 909.

43. Flinn's Estate, 320 Pa. I5, I8r Atl. 492 (1935).

44. Flinn's Estate, $320 \mathrm{~Pa}$. at 23, r8r Atl. at 495. 
occur within the trust estate. They may cause either an increase or a decrease in intact value.

If the shareholders make additional payments to the corporation, this "contributed" or "paid-in" surplus increases the intact value of the shares. ${ }^{45}$ Likewise, if the corporation sells new shares at a price in excess of the book value of such shares, the intact value of all of the shares is increased thereby. ${ }^{46}$ It has been stated broadly that any increase in surplus not attributable to earnings is an increase of intact value. ${ }^{47}$ Whether profits realized from the sale of property are earnings or whether they are increases in intact value is a question, the answer to which is not at this time settled. It will be the subject of detailed discussion in considering the nature of earnings. ${ }^{48}$

The intact value of the shares may be decreased by any "capital loss" sustained by the corporation. ${ }^{49}$ A sale of new shares by the corporation at a price below their book value would decrease, of course, the intact value of all of the shares. ${ }^{50}$ The nature of so-called "capital losses" has not been made clear by the decisions of the supreme court. Such a capital loss was expressly considered in only one of them, namely, Dickinson's Estate, ${ }^{51}$ where the court considered the effect of a very large loss, sustained by a fire insurance company and caused by a conflagration. In that case the loss was so great in amount that it not only wiped out the surplus of the corporation but also caused an impairment in capital. The court held that the result was to reduce the intact value to the book value of the shares after the loss had been charged off. The Orphans' Court of Philadelphia requires such losses to be deducted first from earnings accumulated since the death of the testator, and only the balance of the loss, if any, may be deducted from intact value. ${ }^{52}$ This is a literal application of the rule of Dickinson's Estate, but it results in making the rights of the parties depend entirely upon the magnitude of the loss rather than upon its nature. In Dickinson's Estate the court really had before it an operating loss of such magnitude that some of it, perforce, had to be borne by the intact value. If there is any real foundation for the concept of "capital losses", their incidence should depend not upon their size but upon their character. It

45. Waterhouse's Estate, $308 \mathrm{~Pa}$. at 428, I62 At1. at 296; Packer's Estate (No. I), 29I Pa. at 197, I39 At1. 867; Dickinson's Estate, 285 Pa. at 453, I32 Atl. at 353.

Igo (I9I7).

47. Waterhouse's Estate, 308 Pa. at 428,162 Atl. at 296. Under this rule, the proceeds of an insurance policy on the life of a deceased officer would become a part of intact value. Jones v. Motor Sales Co., 322 Pa. 492, I85 Atl. 809 (I936).

48. Infra pp. 366 to 369 .

49. Waterhouse's Estate, $308 \mathrm{~Pa}$. at 428, I62 Atl. at 296; Packer's Estate (No. I), 29I $\mathrm{Pa}$. at I97, I39 Atl. 867; Nirdlinger's Estate, 290 Pa. at 464, I39 At1. at 203; Dickinson's Estate, $285 \mathrm{~Pa} .449$, 132 Atl. 352.

50. Willcox's Estate, $66 \mathrm{~Pa}$. Super. at rgo.

5I. Dickinson's Estate, 285 Pa. 449, I32 Atl. 352 (1926).

52. Neafie's Estate, 25 D. \& C. 608, 6I7 (Orph. Ct. Phila. 1936). 
may be suggested that the only true "capital losses" are decreases in book value caused by financing operations, losses sustained on assets which were owned by the corporation at the death of the testator, and losses of similar character. Likewise, the only true capital gains ought to consist only of increases in book value caused by transactions of like nature. These are questions which warrant, and will doubtless receive, further clarification when suitable cases arise.

Another problem is presented by an intervening merger of corporations. For example, the trustee holds shares of the $X$ corporation which, after the death of the testator, purchases all the assets of the $Y$ corporation, which it treats on its books as having been worth exactly the purchase price. Still later it becomes necessary to apportion a stock dividend declared by the $X$ corporation. Presumably, the $X$ corporation does not pay, in cash or stock, any more than the assets of the $Y$ corporation are worth and consequently, in the absence of evidence to the contrary, the merger does not change the intact value of the outstanding shares of the $X$ corporation. ${ }^{53}$

All of the foregoing changes in intact value were caused by events occurring entirely within the corporation. But similar changes may be made necessary by events which take place wholly or principally within the trust estate. For example, the life beneficiaries may, on a previous occasion for apportionment, have donated to corpus the shares or cash which they would otherwise have been entitled to receive. This donation may be by express agreement, made the basis of an adjudication, ${ }^{54}$ or it may simply result because the life beneficiaries were at that time ignorant of their rights. ${ }^{55}$ In either event, the effect of the donation presents a vexatious problem when a subsequent occasion for apportionment arises. If the donation consists of shares of stock, the donation merely adds to the intact value a sum equal to the book value of the donated shares. An adjudication, even though based upon an express agreement of the parties, does not have the effect of writing up the intact value of the original shares to the book value of the donated shares. ${ }^{56}$ If, however, the donation consisted of cash, it has no effect whatever upon the intact value and cannot be considered a payment on account of that intact value. ${ }^{57}$

It frequently happens that the determination of intact value is further complicated by the fact that, in the past, the trustee received rights to subscribe which he either exercised or sold. Later there is a stock dividend (or other occasion for apportionment) and both transactions come before the court, at which time it is necessary to determine the intact value. The

53. Jones v. Integrity Trust Co., $292 \mathrm{~Pa}$. at I55, I40 Atl. at 864.

54. Bullitt's Estate, 308 Pa. 413, I62 At1. 288 (I932). court.

55. Neafie's Estate, 25 D. \& C. 608 . This case, however, is now on appeal to the supreme

56. Bullitt's Estate, $308 \mathrm{~Pa} .413$, I62 Atl. 288.

57. Neafie's Estate, 25 D. \& C. 608. 
effect upon intact value of the intervening rights to subscribe depends upon what the trustee did with them. If he exercised them and subscribed to new shares, paying the subscription price out of principal, the intact value of the whole investment is the book value of the original shares plus the purchase price of the new shares. ${ }^{58}$ If he exercised the rights but distributed the new shares to the life beneficiaries, the intact value is unchanged, but the purchase price of the new shares must be taken out of income. ${ }^{59}$ If, instead of exercising the rights, the trustee sold them and now retains the proceeds as principal, the intact value of the investment is the book value of the original shares minus the proceeds of the sale of the rights. ${ }^{60}$

The rules just stated may not apply, however, if an adjudication has intervened between the exercise or sale of the rights to subscribe and the subsequent occasion for apportionment. If, by reason of a failure to press their rights, the life beneficiaries allowed the court to award the subscribed shares (or the proceeds of the sale of rights) entirely to corpus when part or all should have been awarded to income, apparently there would be a donation. ${ }^{61}$ Upon any subsequent occasion for an apportionment the intact value would be increased by the book value of any shares of stock donated to corpus ${ }^{62}$ but would be neither increased nor decreased by a cash donation. ${ }^{63}$

Such are the refinements by which one must determine the intact value to be preserved for the remaindermen. Similar, but less detailed, refinements determine the nature of earnings which may be awarded to the life beneficiaries. After consideration of these, we then may discuss briefly the application of both concepts to the various occasions which call for an apportionment.

\section{The Nature of Earnings}

Any fund which does not represent earnings available for distribution in the form of a dividend ${ }^{64}$ should not be treated as earnings for the purpose now under discussion. However, the converse is not necessarily true. It does not follow that, because a corporation is at liberty to treat a particular fund as earnings or profits available for the declaration of a dividend, such fund constitutes earnings as between life beneficiary and remainderman. ${ }^{65}$ Consequently, the bare fact that the surplus of the corporation

58. Hostetter's Trust, $39 \mathrm{~Pa}$. 572, I8I Atl. 567; Jones v. Integrity Trust Co., $292 \mathrm{~Pa}$. at I53, I40 Atl. at 864 .

59. Jones v. Integrity Trust Co., $292 \mathrm{~Pa}$. at I54, I40 Atl. at 864.

6o. Jones v. Integrity Trust Co., $292 \mathrm{~Pa}$. at I54, I40 Atl. at 864.

6I. Neafie's Estate, 25 D. \& C. 608.

62. Bullitt's Estate, 308 Pa. 413, I62 At1. 288.

63. Neafie's Estate, 25 D. \& C. 608.

64. Jones v. Motor Sales Co., 322 Pa. 492, I85 Atl. 809 (I936) (proceeds of insurance policy on life of deceased officer).

65. For example, earnings accumulated prior to the death of the testator are part of the intact value of the shares. See Waterhouse's Estate, $308 \mathrm{~Pa}$. at 427 , 162 At1. at 296; Nirdlinger's Estate, $290 \mathrm{~Pa}$. at 464, 139 Atl. at 203. 
has increased since the death of the testator does not necessarily indicate that the surplus has been increased out of earnings. ${ }^{66}$ For example, profits derived by the corporation from the sale of capital assets owned at the death of the testator are not earnings. ${ }^{67}$ And a distribution of corporate property, acquired by the corporation before the death of the testator, is not a distribution out of earnings. ${ }^{68}$

However, earnings accumulated since the death of the testator do not lose their character as such merely because the management of the corporation has transferred them to another corporation as a part of an elaborate plan of reorganization or reincorporation, ${ }^{69}$ nor do they cease to be earnings available for the life beneficiary merely because the corporation has invested them in permanent capital assets. ${ }^{70}$ Consequently, a stock or scrip dividend, ${ }^{71}$ or the portion of the proceeds of a sale of the shares, ${ }^{72}$ representing capital assets acquired from earnings accumulated since the death of the testator, should be awarded to the life beneficiary.

This problem is encountered most frequently when it is discovered that some of the increase in surplus is due to profits made by the corporation from the sale of real estate subsequent to the death of the testator. Such profits may be considered as earnings, under the foregoing rules, if the real estate was originally acquired by the corporation out of earnings accumulated subsequent to the death of the testator. Even though the corporation owned the real estate when the testator died, the profits may still be earnings if the principal business of the corporation is to deal in real estate. ${ }^{73}$ In all other cases, however, profits derived from the sale of real estate should be treated as additions to the intact value, rather than as earnings.

It must not be supposed that earnings are limited to profits derived from the regular or principal business of the corporation. Earnings also

66. Graham's Estate, $296 \mathrm{~Pa}$. 436, 440, I46 Atl. III, II2 (I929).

67. Graham's Estate, I98 $\mathrm{Pa}, 216,47$ At1. IIO8 (IgOI) (proceeds of condemnation of property of corporation); Vinton's Appeal, $99 \mathrm{~Pa}$. 434 (I882) (proceeds of sale of property of corporation) ; Restatenent, Trusts, $\$ 236$, comment $z$.

68. Eisner's Appeal, I75 Pa. I43, I48-I49, 34 Atl. 577, 579 (I896).

69. Daily's Estate, 323 Pa. 42, I86 Atl. 754 (I936).

70. Chauncey's Estate, 303 Pa. 44I, 448, I54 At1. 8I4, 8I6 (I93I) ; Boyer's Appeal, 224 Pa. I44, 73 Atl. 320 (I909) ; Cassatt's Estate, I05 Pa. Super. I4, I58 Atl. 586 (I932) ; McCahan's Estate, I8 D. \& C. I7I (Orph. Ct. Phila. I933), rev'd on other points, 3I2 Pa. 5I5, I68 Atl. 685 (I933); see Eisner's Appeal, I75 Pa. at 148-I49, 34 Atl. at 579. Accord: RESTATEMENT, Trusts, $\$ 236$, comment $z$.

7I. Chauncey's Estate, 303 Pa. at 448, I54 Atl. at 8I6; Boyer's Appeal, 224 Pa. I44, 73 Atl. 320. The dictum of the lower court to the contrary printed with the supreme court opinion in Vinton's Appeal, $99 \mathrm{~Pa}$. 434, 438 (I882), must now be regarded as overruled.

72. Cassatt's Estate, I05 Pa. Super. I4, I58 Atl. 586.

73. Mandeville's Estate, $286 \mathrm{~Pa}$. 368, 37I, I33 Atl. 562, 563 (I926) ; see Thomson's Estate, I53 Pa. 332, 26 Atl. 653 (I893); Oliver's Estate, I36 Pa. 43, 20 Atl. 527 (1890) (trustee held interests in an unincorporated association and a joint stock company, instead of shares of stock of a corporation). Accord : RESTATEMENT, TRUSTS, $\$ 236$, comment $z$. 
include profits derived from "miscellaneous sources", 74 which, however, are not specified with any degree of clarity. Thus surplus earnings acquired through a merger and carried in the surplus account of the corporation which acquired them are earnings of the latter. ${ }^{75}$

One of the "miscellaneous sources" which has caused a certain degree of confusion is the profit derived by the corporation from the sale of stocks or bonds of other corporations which it owned. Of course, if the corporation issues its own bonds above par, or issues its own stock at a price above book value, the gain should not be treated as earnings. ${ }^{76}$ If, however, it sells its holdings of securities of another corporation, a different question is presented.

In Graham's Estate, ${ }^{77}$ the supreme court stated that profits from the sale of bonds are not income. However, in Channcey's Estate, ${ }^{78}$ this statement was in effect retracted. Consequently, the Orphans' Court of Philadelphia has now decided that profits derived from the sale by the corporation of stock of another corporation constitute earnings, even though the securities in question are shares of stock of a wholly owned subsidiary. ${ }^{\mathbf{7 9}}$ In none of these cases has any attention been paid to the fact that some of the securities were owned by the corporation at the death of the testator. ${ }^{80}$

That fact would seem to be of vital importance, however. If the securities were owned by the corporation at the death of the testator, they would be part of the intact value, and any profit realized on their subsequent sale would not be earnings, ${ }^{81}$ unless the principal business of the corporation was to deal in such securities. ${ }^{82}$ But if the corporation acquired the securities out of earnings accumulated subsequent to the death of the testator, any subsequent profits should be treated as earnings. ${ }^{83}$ Although this distinction apparently has never been urged in any reported case, it is supported nevertheless by authorities specifically dealing with profits realized on

74. Waterhouse's Estate, $308 \mathrm{~Pa}$. at 428, I62 Atl. at 296; Chauncey's Estate, $303 \mathrm{~Pa}$. at 448, 154 Atl. at 8I6; RESTATEMENT, TRUSTS, \$ 236, comment $v$.

75. Chauncey's Estate, 303 Pa. at 448, I54 At1. at 8I6. I90.

76. Dickinson's Estate, 285 Pa. 449, r32 Atl. 352; Willcox's Estate, $66 \mathrm{~Pa}$. Super. I82, (1929).

77. Io D. \& C. 695 (Orph. Ct. Phila. I928), aff'd, 296 Pa. 436, 440, I46 Atl. IIr, rI2

78. Chauncey's Estate, 303 Pa. at 448, 154 At1. at 816.

79. Dobson's Estate, 26 D. \& C. I54 (Orph. Ct. Phila. 1936) ; cf. McCahan's Estate, I8 D. \& C. I7I (Orph. Ct. Phila. I933), rez'd on other points, 3I2 Pa. 5I5, I68 At1. 685 (I933). If such profits are earnings, it would follow that losses would be properly treated as operating losses, deductible from accumulated earnings, and not capital losses deductible from intact value. Neafie's Estate, 25 D. \& C. 608 (Orph. Ct. Phila. 1936).

8o. See, $e . g$., the securities whose sale was involved in Dobson's Estate, 26 D. \& C. I54.

8I. Graham's Estate, I98 Pa. 216, 47 Atl. I108; Vinton's Appeal, 99 Pa. 434; cf. RESTATEMENT, TRUSTS, $\$ 236$, comment $v$, the second sentence of which appears to be inconsistent with the second paragraph of comment $z$.

82. See cases collected supra note 73.

83. See cases collected supra notes $70,72$. 
the sale of other so-called "capital assets" by the corporation. As a matter of logic, therefore, it appears to be sound.

It sometimes happens that a corporation, during the trust period, sets up a reserve for depreciation in excess of the amount required for that purpose. This fund, having been established out of earnings which would otherwise have been available for distribution to the life beneficiary, does not lose its character as earnings and, if subsequently distributed, should be awarded as income. ${ }^{84}$

Future decisions undoubtedly will give additional aid in determining what constitutes earnings and what does not. It may also be expected that further principles for the determination of intact value will be established. It is believed, however, that the foregoing rules relating to earnings and to intact value apply regardless of the nature of the particular occasion for apportionment which the court is considering. However, in some cases the burden is on the remainderman to show that a particular fund does not represent earnings, or that its award to the life beneficiary will impair the intact value of the shares. In other cases, the burden is on the life beneficiary to show that a particular fund does represent earnings accumulated by the corporation since the creation of the trust and that its award to him will not impair the intact value of the shares. These differences will be pointed out in considering the particular occasions which give rise to the question of apportionment.

\section{DIVIDENDS}

By far the most common occasion for controversy between life beneficiary and remainderman is presented by the declaration of a dividend. A dividend may be "ordinary" or "extraordinary". Indeed, it may partake of the nature of both.

All dividends paid, out of earnings which accrued to the corporation after the death of the testator are income, regardless of their amount or the regularity of their declaration. ${ }^{85}$ While in such a case, therefore, it generally makes no difference whether the dividend is "ordinary" or "extraordinary", in other cases it becomes very important to distinguish between ordinary and extraordinary dividends because the applicable rules are entirely different.

Ordinary dividends have been variously defined as dividends paid at customary rates and uniform intervals, ${ }^{86}$ as usual or customary dividends at a fixed sum or rate and paid at regular periods, ${ }^{87}$ or as periodic declara-

84. McCahan's Estate, I8 D. \& C. I7I, rev'd on other points, 312 Pa. 515, 168 Atl. 685.

85. Opperman's Estate (No. I), 319 Pa. 455, 464, I79 At1. 729, 734 (I935).

86. Opperman's Estate (No. I), 319 Pa. at 46I, 464, I79 At1. at 733, 734; Given's Estate, $323 \mathrm{~Pa} .456,46 \mathrm{I}, \mathrm{I} 85$ Atl. 778, 780 (1936) ;

87. Nirdlinger's Estate, 290 Pa. at 462, r39 Atl. at 202. 
tions involving small sums or rates. ${ }^{88}$ An extraordinary dividend has been defined as a dividend which is unusual in form and amount and paid at irregular intervals. ${ }^{89}$

This distinction, which might seem tolerably easy to apply, may nevertheless lead to unexpected difficulty. For example, a corporation has no fixed or regular dividend policy. From time to time, as profits warrant, it is in the habit of making distributions to shareholders. These distributions are very substantial in amount but are at no uniform rate. In some years there will be no distribution at all, and in other years a dividend as large as thirty-three dollars a share will be paid. In other words, it is the ordinary practice of the corporation to declare a series of extraordinary dividends. The auditing judge, to whom this problem was presented, held that the last of a series of such dividends was "ordinary" but nevertheless found it impossible to apportion it between the successive life beneficiaries on a per day basis, as bond interest is apportioned, in accordance with the requirements of Section 22 of the Fiduciaries Act. ${ }^{90}$ The court en banc reached the same conclusion but said that the dividend belonged to a third classification, being "not so extraordinary that its source will be inquired into, and which, therefore, must be called an ordinary dividend, and yet so irregular that it cannot be apportioned, and must lie where it falls".91 Consequently, the dividend was awarded to the person entitled to the income of the estate when the dividend was declared, even though it was paid out of earnings that had accrued during a prior life estate. The dividend, therefore, did not come within Section 22 of the Fiduciaries Act, which lays down the only exception to the general rule that ordinary dividends are not apportionable and must be awarded to the person then entitled to the income of the trust estate. ${ }^{92}$ That statute applies only to wills and provides only for the apportionment of "ordinary" dividends at the end of a life estate or an estate for years on a per day basis as bond interest is apportioned. ${ }^{93}$

In accordance with the general rule, ordinary dividends, if paid out of earnings, are income even though they were paid out of earnings made by the corporation prior to the death of the testator. ${ }^{94}$ It has been said that

88. Earp's Appeal, $28 \mathrm{~Pa}$. 368, 375 (I857). For additional discussion, see Restatenrent, TRUSTS, \$236, comment $c$.

89. Nirdlinger's Estate, $290 \mathrm{~Pa}$. at 462, I39 Atl. at 202.

9o. Pa. Stat. Ann. (Purdon, I930) tit. 20, $\$ 634$.

9I. Nirdlinger's Estate, 26 D. \& C. 3, I8 (Orph. Ct. Phila. I936).

92. In support of the general rule, see Opperman's Estate (No. I), 319 Pa. 455, I79 Atl. 729 ; Waterhouse's Estate, $308 \mathrm{~Pa}$. at 428, 162 Atl. at 296; Nirdlinger's Estate, $290 \mathrm{~Pa}$. at 462 , 478, 139 Atl. at 202, 208; McKeown's Estate, 263 Pa. at 86, I06 Atl. at I9I; Earp's Appeal, $28 \mathrm{~Pa}$. at 375 ; RESTATEMIENT, TRUSTs, $\$ 236$, comments $c-f$.

93. It is believed that this is a correct statement of the limited scope of the statute. Opperman's Estate (No. I), 319 Pa. 455, I79 Atl. 729; Given's Estate, 323 Pa. at 46r, I85 Atl. at 780 ; Thompson's Estate, 6 D. \& C. 503 (Orph. Ct. 1925); Nirdlinger's Estate, 26 D. $\&$ C. at I5. Further light on this at present doubtful question may be expected from the decision on the pending appeal in Nirdlinger's Estate.

94. Opperman's Estate (No. I), 319 Pa. 455, I79 Atl. 729 ; Restatement, Trusts, \$ 236, comment $d$. 
this rule does not apply when "unusual circumstances" are present. The court has, however, defined an "unusual circumstance" as being one which comes from some administrative or corporate act within the corporation or some breakdown within the corporate structure, rather than a circumstance set up by the fiduciary or by the court. ${ }^{95}$ The relation between the value of the trustee's holding of a particular stock and the value of the whole trust estate is not an "unusual circumstance". On the other hand, where the corporation reduces the number of shares of stock or the par value of the shares, in order to provide a surplus out of which ordinary dividends can be paid, this act is an "unusual circumstance" and dividends paid out of such surplus constitute a return of capital and will be awarded to principal. ${ }^{06}$

If an ordinary dividend was declared by the corporation prior to the death of the testator but made payable at a date subsequent thereto, the disposition of the dividend depends entirely upon the date fixed by the dividend resolution for the ascertainment of the shareholders to whom the dividend shall be paid; if no date is specified, such a dividend is awarded to corpus. The same is true if the resolution specifies that the dividend shall be paid to shareholders of record on a date prior to the death of the testator; but if the resolution directs that the dividend be paid to shareholders of record on a date subsequent to the death of the testator, the dividend is awarded in its entirety to income. ${ }^{97}$

The rules with respect to extraordinary dividends are entirely different. The prima facie presumption is that every such dividend was declared out of earnings accumulated by the corporation since the death of the testator, ${ }^{98}$ and consequently such dividends are presumptively income. ${ }^{99}$ The remaindermen have the burden of proving either that the extraordinary dividend was not in fact paid from earnings, or that the entire dividend cannot be awarded to income without impairing the intact value of the shares. ${ }^{100}$

95. Opperman's Estate (No. I), 319 Pa. at 460 , I79 Atl. at 732.

96. Opperman's Estate (No. I), 319 Pa. at 462, I79 Atl. at 732. A corporate reorganization involving the creation of two new corporations, a holding company and an operating company, and an exchange of the trustee's shares for the shares of the holding company, is an unusual circumstance. Daily's Estate, $323 \mathrm{~Pa}$. 42, I86 At1. 754 (1936).

97. Opperman's Estate (No. r), 319 Pa. at 464, I79 At1. at 734; Restatenent, TRUsts, $\S 236$ (a), comments $i$ to $k$. But cf. Given's Estate, $323 \mathrm{~Pa}$. at 460 , I85 Atl. at 780 .

98. Hostetter's Trust, $319 \mathrm{~Pa}$. at 574 , I8I Atl. at 568 .

99. Waterhouse's Estate, $308 \mathrm{~Pa}$. at 428 , I62 Atl. at 296; Chauncey's Estate, $303 \mathrm{~Pa}$. at 446, I54 At1. at 8I5; Graham's Estate, 296 Pa. at 439, I46 Atl. at II2; Nirdlinger's Estate, $290 \mathrm{~Pa}$. at 478, I39 Atl. at 208; McKeown's Estate, 263 Pa. at 86, I06 Atl. at I9I; Stokes's Estate (No. I), $240 \mathrm{~Pa} .277,283,87$ At1. 971, 973; Boyer's Appeal, $224 \mathrm{~Pa}$. at 152, 73 At1. at 323 ; Earp's Appeal, $28 \mathrm{~Pa}$. 368 ; cf. Restatenent, Trusts, $\$ 236$ (b), which apparently negatives this presumption.

I00. Waterhouse's Estate, $308 \mathrm{~Pa}$. at 429, 162 At1. at 296; Chauncey's Estate, $303 \mathrm{~Pa}$. at 446, I54 Atl. at 8I5; McKeown's Estate, $263 \mathrm{~Pa}$. at 86, I06 Atl. at I9I-192; Stokes's Estate (No. I), 240 Pa. at 283, 87 Atl. at 973; Boyer's Appeal, 224 Pa. at I52, 73 At1. at 323; Earp's Appeal, $28 \mathrm{~Pa}$. 368; cf. Restatenent, Trusts, $\$ 236$ (b), which apparently reverses the burden of proof. 
If the remaindermen can successfully meet the burden of proof which is imposed upon them, the court will award to corpus such portion of the extraordinary dividend which may be shown necessary to preserve the intact value of the original shares. ${ }^{101}$ And the court will likewise award to corpus any portion of the dividend which has been paid out of increased capital assets as distinguished from earnings, ${ }^{102}$ irrespective of any question of the impairment of intact value.

These rules relating to extraordinary dividends apply whether the dividend was paid in cash, ${ }^{103}$ shares of stock of the same corporation, ${ }^{104}$ shares of stock of another corporation, ${ }^{105}$ scrip or dividend obligations, ${ }^{106}$ or liberty bonds. ${ }^{107}$ The form of the dividend is immaterial. In a few cases the corporation, instead of declaring a stock dividend, has declared an extraordinary cash dividend and at the same time given the shareholders the right to subscribe to additional shares in an amount exactly equal to the extraordinary cash dividend. This kind of a transaction is in substance a stock dividend and is treated accordingly by the courts. ${ }^{108}$

In all of the foregoing instances, the court has been dealing with cases where the trustee held shares of common stock. At first sight it would seem that no such questions would arise where the trustee holds shares of preferred stock, paying dividends at a specified rate and at fixed intervals. Nevertheless, we may expect that the courts will soon be called upon to deal with a type of case of which the writer knows of only two examples in jurisdictions applying the Pennsylvania rules, neither of these cases being a decision of the court of last resort.

Ior. Waterhouse's Estate, $308 \mathrm{~Pa}$. at 428, I62 Atl. at 296; Chauncey's Estate, $303 \mathrm{~Pa}$. at 445, I 54 Atl. at 8I5; Nirdlinger's Estate, 290 Pa. at 478, I39 Atl. at 208; Flaccus's Estate, $283 \mathrm{~Pa}$. at I94, r29 At1. at 77; Waterman's Estate, $279 \mathrm{~Pa}$. at 494, I24 Atl. at I67; McKeown's Estate, $263 \mathrm{~Pa}$. at 86, 106 Atl. at 192; Thompson's Estate, $262 \mathrm{~Pa}$. 278, 105 At1. 273 (I9r8) ; Sloan's Estate, 258 Pa. 368, I02 Atl. 3I (I9I7) ; Earp's Appeal, 28 Pa. 368.

I02. Waterhouse's Estate, $308 \mathrm{~Pa}$. at 428, I62 Atl. at 296; Chauncey's Estate, $303 \mathrm{~Pa}$. at 447, I54 Atl. at 8I 5 ; REstateMnent, TRUSTs, \$236 (f) and comment $z$.

I03. Mandeville's Estate, 286 Pa. 368, I33 Atl. 562; Thompson's Estate, I53 Pa. 332, 26

Atl. 653; Smith's Estate, I40 Pa. 344, 21 At1. 438; Oliver's Estate, I36 Pa. 43, 20 Atl. 527 ;

Vinton's Appeal, 99 Pa. 434; Restatement, Trusts, \$236 (b) and comment $s$.

I04. Flinn's Estate, 320 Pa. 15, I8I Atl. 492; Bullitt's Es! ate, 308 Pa. 4I3, I62 Atl. 288; Chauncey's Estate, 303 Pa. 44I, I54 Atl. 8I4; Maris's Estate, 30I Pa. 20, I5I Atl. 577 ; Packer's Estate (No. I), 29I Pa. 194, I39 Atl. 867 ; Dickinson's Estate, 285 Pa. 449, I32 At1. 352; Mallory's Estate, $285 \mathrm{~Pa}$. I86, I3I Atl. 714; Harkness's Estate, $283 \mathrm{~Pa}$. 464, I29 Atl. 458; Wittmer's Estate, 283 Pa. 3 II, I29 At1. 85; Flaccus's Estate, 283 Pa. I85, I29 Atl. 74 ; Sloan's Estate, $258 \mathrm{~Pa}$. 368, 102 At1. 3I ; Earp's Appeal, $28 \mathrm{~Pa}$. 368; Phila. Trust, Safe Deposit and Ins. Company's Appeal, 24 W. N. Cas. 137, 16 Atl. 734; Willcox's Estate, 66 Pa. Super. Ct. I82; Restatement, TRUSts, $\$ 236$ (b) and comment $u$.

105. Eisner's Appeal, r75 Pa. I43, 34 Atl. 577; Restatement, Trusts, \$ 236 (b) and comment $t$.

106. Boyer's Appeal, 224 Pa. I44, 73 Atl. 320; Robinson's Trust, 218 Pa. 48I, 67 At1. 775 ; Phila. Trust, Safe Deposit and Ins. Company's Appeal, 24 W. N. Cas. I37, I6 Atl. 734 (I889); Restatement, Trusts, $\$ 236$ (b) and comment $t$.

I07. Waterman's Estate, $279 \mathrm{~Pa}$. 49r, I24 Atl. I66.

108. Thompson's Estate, $262 \mathrm{~Pa}$. 278, I05 Atl. 273; Stokes's Estate (No. 1), $240 \mathrm{~Pa} .277$,

87 Atl. 97I; Smith's Estate, I40 Pa. 344, 21 Atl. 438. 
Suppose that the trustee holds shares of cumulative preferred stock, on which a large amount of unpaid back dividends have accrued. If the corporation then becomes prosperous and pays off the back dividends, the question will arise as to whether these payments are income or principal. In this connection it must be noted that the back dividends may have accrued before the death of the testator or after, or partly both. They may be paid off from earnings accumulated by the corporation before or after the death of the testator, or both. Moreover, the back dividends may have accrued in whole or in part during a preceding life estate and may have been paid in whole or in part from earnings accumulated by the corporation during such preceding life estate.

As might be expected, jurisdictions following the so-called "Massachusetts rule" base the result upon the medium of payment and the back dividends are either income or principal depending upon whether they are paid in cash or in shares of stock. ${ }^{109}$ However, even in Massachusetts the unpaid dividends accrued at the death of the testator are not regarded as a chose in action which became a part of the principal of the estate. ${ }^{110}$

This would seem a correct application of the well settled rule that a preferred shareholder is not a creditor of the corporation. ${ }^{111}$ Consequently, the back dividends accrued at the death of the testator should not be treated as a part of the intact value if, indeed, a preferred stock can be said to have any intact value. The cumulative feature of preferred stock is simply a prior right to receive income. It should not determine the allocation of that income when received by a trustee.

The Restatement of the Law of Trusts has adopted the rule that all payments of back preferred dividends are income to be awarded to the person at that time entitled to receive the income of the trust estate, ${ }^{112}$ provided only that they are paid out of earnings. It makes no difference when the back dividends accrued or when the earnings were accumulated. The Restatement treats all such payments as "ordinary" dividends, and if this is correct, the result is in accord with our general rule that, except in cases governed by Section 22 of the Fiduciaries Act, ordinary dividends are not apportionable but belong entirely to the life beneficiary. ${ }^{113}$

The rule adopted by the Restatement is apparently based entirely upon Thompson v. New York Trust Co. ${ }^{114}$ In that case back dividends on preferred shares were paid out of earnings accumulated by the corporation

r09. Boston Safe Deposit \& Trust Co. v. Adams, 219 Mass. 175, I06 N. E. 590 (1914); Coolidge v. Grant, 25 I Mass. 352, I46 N. E. 7I9 (I925).

110. Boston Safe Deposit \& Trust Co. v. Adams, 219 Mass. at I77, 106 N. E. at 59 r.

III. Mitchell v. Liberty Clay Products Co., 291 Pa. 282, 290, I39 At1. 853, 855 (I927).

II2. Section 236 , comments $o$ and $p$.

II3. See cases collected supra note 92.

II4. 107 N. Y. Misc. 245, 177 N. Y. Supp. 299 (Sup. Ct. I9I9), aff'd without opinion, I9I App. Div. 904, I8r N. Y. Supp. 956 (Ist Dep't, I920). 
prior to the creation of the trust. It is not clear when the back dividends accrued but apparently they accrued both prior to and subsequent to the creation of the trust. Notwithstanding the source of the fund from which the back dividends were paid, the court held that they were entirely the property of the life beneficiary. The result may be attributable in part to the language of the deed of trust which expressly directed that "dividends" be paid to the life beneficiary. However, the case cannot be summarily dismissed on this hypothesis because the court was professedly applying the Pennsylvania rule, which had been adopted by the court of appeals. ${ }^{115}$ In doing so, the court treated the dividend as "ordinary" and, therefore, not subject to apportionment.

So far as is known, the problem has been considered to date in only one Pennsylvania decision. ${ }^{116}$ That case was the audit, by the Orphans' Court of Delaware County, of the second trustees' account in the Estate of John P. Crozer. ${ }^{117}$ There the corporation paid back dividends, most or all of which accrued prior to the death of the testator, out of earnings accumulated by the corporation thereafter. The auditing judge, in a carefully reasoned adjudication, followed the Thompson case and the Restatement and held that the dividend payments were income, awarding them to the life beneficiaries. This decision was accepted by the parties.

The suspension of preferred dividends, caused by the business depression, has laid the foundation for numerous cases which will doubtless come before the courts in due course. The strongest case for the life beneficiary will be presented where the back dividends accrued subsequent to the death of the testator and were paid from earnings which also were accumulated subsequent to the death of the testator. The strongest case for the remainderman will be presented where the back dividends accrued prior to the death of the testator and were paid from earnings which were accumulated prior to the death of the testator. Thompson v. New York Trust Co. ${ }^{118}$ presents very nearly the latter situation, but nevertheless the dividends were awarded entirely to the life beneficiary. Crozer's Estate ${ }^{110}$ is an intermediate case because the back dividends were paid from earnings of the corporation accumulated after the death of the testator. Innumerable other intermediate cases can be readily imagined and will doubtless occur. Until the supreme court shall have passed upon this problem, doubt and difference of opinion will exist. Meanwhile, it can be said only that the

II5. Matter of Osborne, 209 N. Y. 450, ro3 N. E. 723 (I9I3).

II6. It was not considered in Given's Estate, 323 Pa. 456, I85 Atl. 778 (1936), in which back dividends were declared and paid after the death of the life beneficiary. The court awarded them to the remaindermen but the result was based upon the language of the will.

II7. 27 D. \& Co. I79 (Orph. Ct. Del. Co. I936).

II8. I07 N. Y. Misc. 245, 177 N. Y. Supp. 299, aff'd without opinion, Igr App. Div. 904, I8I N. Y. Supp. 956.

II9. 27 D. \& C. 179 (Orph. Ct. Del. Co. I936). 
rule of the Restatement, which seems to be theoretically sound, is supported by the few existing authorities and thus far has been followed in all cases where it was called to the attention of the lower courts.

\section{DistribUtions IN LiQUIDATION}

The purpose of payments in liquidation is, of course, to distribute to the shareholders the entire assets of the corporation which remain after the payment of debts. These payments represent not only the earnings which the corporation has accumulated since the death of the testator but also the capital assets which the corporation owned at that time, together with any enhanced value that may be realized thereon.

It was recognized at a comparatively early date that the life beneficiary should receive such portion of the proceeds of a corporate liquidation as is actually a distribution of earnings accumulated by the corporation since the death of the testator. ${ }^{120}$ But, by reason of the nature of distributions in liquidation, there can scarcely be any presumption that the corporation is distributing merely its earnings. Consequently, the burden rests upon the life beneficiary to prove the amount of such accumulated earnings ${ }^{121}$ and only to the extent that he does so will he participate in a distribution in liquidation. ${ }^{122}$ Logically, he ought also to prove that the particular earnings are actually represented in a particular payment. However, this would be an impossible burden, and accordingly, if the life beneficiary proves that earnings to the extent of a certain sum per share have been accumulated since the death of the testator, he will receive that sum out of the first payment, if the intact value will not be impaired thereby. ${ }^{123}$

The foregoing rules apply to a partial ${ }^{124}$ as well as to a total liquidation. They likewise apply to a transaction which is in substance a liquidation of the corporation although, perhaps, not technically a liquidation in form. ${ }^{125}$

r20. Connolly's Estate (No. I), I98 Pa. I37, 47 At1. II25 (I90I) ; McKeown's Estate, $263 \mathrm{~Pa} .78$, 86, I06 Atl. I89, I92 (I9I9) ; McCahan's Estate, I8 D. \& C. I7I (Orph. Ct. Phila. 1932), rev'd on other points, 312 Pa. 515, I68 Atl. 685 (1933); REstatenent, TruUsts, $\S 236(\mathrm{~d})$, comment $x$.

I2I. McKeown's Estate, $263 \mathrm{~Pa}$. at 86, I06 Atl. at I92; McCahan's Estate, I8 Pa. D. \& C. I7I, rev'd on other points, 312 Pa. 515, I68 At1. 685 .

I22. Vinton's Appeal, 99 Pa. 434 (I882), and cases collected supra note I20.

I23. All of our cases proceed on the theory that the most recently acquired earnings are first paid out by the corporation. Unfortunately, no case can be cited in which this theory is expressly recognized.

124. Vinton's Appeal, 99 Pa. 434; Restatement, Trusts, $\$ 236$ (d), comment $x$.

I25. McKeown's Estate, 263 Pa. at 83, 84, 86, ro6 Atl. at I9I, I92, in which case the trustee, who held shares of stock of corporation $A$, sold his shares to corporation $B$, which had purchased all the assets of corporation $A$. The court held that the transaction was, in substance, a liquidation of corporation $A$. See also Daily's Estate, $323 \mathrm{~Pa}$. 42, I86 Atl. 754 (1936), where the trustee exchanged his shares for the shares of a new holding company which owned all the shares of a new operating company to which the assets of the original corporation had been transferred. 


\section{MERGERS}

It frequently happens that two or more corporations, in one of which the trustee is a shareholder, enter into a merger, and the trustee thereupon exchanges his shares for shares in a new corporation. If the trustee receives the same number of shares of new stock in exchange, the life beneficiary has no right to an apportionment, even though the book value of the new shares exceeds the intact value of the original shares. ${ }^{126}$ In such a case there can be no apportionment until the new corporation declares an extraordinary cash or stock dividend, or is liquidated, or until the trustee sells the new shares at a price which reflects the increased book value. ${ }^{12 \pi}$ If, however, the trustee receives in exchange a greater number of shares of the new corporation, it has been held by a lower court that the excess constitutes a distribution in the nature of an extraordinary dividend and should, therefore, be awarded to the life beneficiary under the rules which govern such dividends. ${ }^{128}$

\section{Rights to SubscRibe}

Prior to 1928 there was considerable conflict and uncertainty among the decisions dealing with rights to subscribe, a fact of which the courts had become well aware. ${ }^{129}$ In that year, the supreme court laid down the rules which apply when the trustee receives rights to subscribe and exercises them. ${ }^{130}$ In 1932 the court considered the rules which apply if the trustee, instead of exercising the rights, sells them. ${ }^{131}$ The difference lies in the burden of proof, but that, of course, is an extremely important difference.

If the trustee exercised the rights and subscribed to new shares by a payment made from corpus, the intact value of the investment is the intact value of the original shares plus the purchase price of the new shares. ${ }^{132}$ Enough of the shares, at their then book value, are awarded to corpus to preserve the intact value thus ascertained, and the balance of the shares are awarded to the life beneficiary. ${ }^{133}$ The presumption is that the shares in excess of the number required to preserve the intact value represent earnings

126. Buist's Estate, 297 Pa. 537, I47 At1. 606 (rg29), aff'g, I2 D. \& C. I59 (Orph. Ct. Phila. I929).

I27. Buist's Estate, 297 Pa. at 543, I47 Atl. at 608.

I28. Graham's Estate, ro D. \& C. 695 (Orph. Ct. Phila. I928), aff'd, 296 Pa. 436, I46 At1. III (I929) (the point now under discussion was not passed upon by the supreme court). The view of the court below is supported by the reasoning in Daily's Estate, 323 $\mathrm{Pa}$. 42, I86 Atl. 754 (1936), where additional shares received in a reincorporation were apportioned.

I29. For discussions of the conflicting decisions, see Nirdlinger's Estate, $290 \mathrm{~Pa}$. at 466 , I39 Atl. at 203-204, and the adjudication of the late Judge Gest in Corr's Estate, 29 Dist. Rep. 281 (Orph. Ct. Phila. I920).

I30. Jones v. Integrity Trust Co., $292 \mathrm{~Pa}$. at I53, I40 Atl. at 863.

I3I. Waterhouse's Estate, $308 \mathrm{~Pa}$. 422 , I62 Atl. 295.

132. Hostetter's Trust, 3I9 Pa. 572, I8I At1. 567.

I33. Ibid.; Jones v. Integrity Trust Co., $292 \mathrm{~Pa}$. at I53, I40 At1. at 863. Contra: RESTATEMENT, TrUSTS, $\$ 236$ (c) and comment $w$. 
accumulated by the corporation since the death of the testator. ${ }^{134}$ The burden is upon the remainderman to prove the contrary.

If, however, the trustee sells the rights instead of exercising them, the proceeds are presumptively principal. The burden of proof rests upon the life beneficiary, and he is entitled to receive only such part of the proceeds as he proves to be attributable to accumulated earnings. ${ }^{135}$ He cannot, of course, receive any portion attributable to increases of capital assets or to the speculative value, enhanced market value or earning power of the stock. $^{136}$

It is difficult to see why the burden of proof should differ in these cases. The substance of the transaction is that the trustee received rights to subscribe, and the burden of proof should not depend merely upon what the trustee does with them. All of the advances made by the recent decisions are based upon the rule that the rights of the parties depend upon the substance of the transaction and not upon its mere form. It is therefore unfortunate that there should be this apparent difference in the burden of proof, based not upon substance but upon form. Perhaps future decisions will make it clear that no such distinction is intended.

In passing, it should be repeated that the declaration of a dividend coupled with the right to use the dividend to purchase new shares is regarded as being in substance a stock dividend. ${ }^{137}$ It therefore would seem to be governed by the rules relating to extraordinary dividends, rather than by the rules governing rights to subscribe.

The recent rules which have just been discussed have rendered obsolete a number of earlier cases. It will be not unprofitable to consider the earlier cases briefly for the purpose of determining which of them are still in apparent good standing.

A leading early case held that rights to subscribe to shares of the same corporation were principal as a matter of law, whether the rights were exercised or sold. ${ }^{138}$ Although this is the rule which has been adopted by the Restatement of the Law of Trusts, ${ }^{139}$ it is no longer the law of Pennsylvania. Equally obsolete are cases indicating that the proceeds of rights are income as a matter of law. ${ }^{140}$

134. Hostetter's Trust, $319 \mathrm{~Pa}$. at 574, I8I Atl. at 568.

135. Waterhouse's Estate, $308 \mathrm{~Pa}$. at 430, I62 At1. at 297; Biddle's Appeal, $99 \mathrm{~Pa} .278$ (1882) ; cf. Noblit's Estate, I5 D. \& C. 202 (Orph. Ct. Phila. I93I) ; Burton's Estate, 12 D. \& C. 605 (Orph. Ct. Phila. I929).

136. Waterhouse's Estate, $308 \mathrm{~Pa}$. at 430, I62 Atl. at 297.

I37. See cases collected supra note 108.

I38. Eisner's Appeal, I75 Pa. 143, 34 At1. 577. Cf. Moss's Appeal, 83 Pa. 264 (I877); Corr's Estate, $29 \mathrm{~Pa}$. D. R. 28I (1920). In Veech's Estate, $74 \mathrm{~Pa}$. Super. 373 (I920), the same rule was applied to rights to subscribe to shares of preferred stock of the same corporation.

I39. Section 236 (c) and comment w.

I40. Wiltbank's Appeal, 64 Pa. 256 (I870). 
However, the problem of rights to subscribe to the shares of another corporation does not appear to be touched by the recent cases. Suppose the trustee holds shares of Corporation $A$ and thereby receives rights to subscribe to shares (or bonds) of Corporation $B$. In such a case it has been held that the rights, ${ }^{141}$ or the profit on the shares acquired by their exercise, ${ }^{142}$ are income as a matter of law. ${ }^{143}$ It can be strongly argued that these cases are still good law. The intact value of the shares of Corporation $A$ would not seem to be affected, unless Corporation $B$ was its subsidiary and the issuance of the rights would decrease the book value of the shares of Corporation $B$, which were among the assets of Corporation $A$. On the other hand, it may be argued that the rights can scarcely be considered a distribution of earnings on the part of Corporation $A$, whose shares the trustee holds, and therefore the life beneficiary is not entitled to them.

All of the foregoing occasions for apportionment were created by events which took place wholly within the corporation whose shares were held by the trustee. However, an apportionment may be made necessary by certain events which take place wholly or principally within the trust estate.

\section{Proceeds of Sales of Shares of Stock}

Prior to I927 it was generally considered to be the law that there could be no occasion for apportionment without some act on the part of the corporation which amounted to a distribution of earnings. ${ }^{144}$ However, a sale by the trustee was considered to require an apportionment where the sale was in substance a liquidation of the corporation. ${ }^{145}$ It represented but a slight step forward to consider an ordinary sale in the market as being a liquidation, at least of the holding of the trustee. ${ }^{146}$

However, as in the case of a true liquidation, ${ }^{147}$ the proceeds of a sale of the shares are prima facie principal ${ }^{148}$ because there is no express or implied declaration by the corporation that they represent earnings. The

I4I. Eisner's Appeal, I75 Pa. I43, 34 Atl. 577; cf. Thomson's Estate, I53 Pa. at 339, 26 Atl. at 653 .

I42. Kemble's Estate, 20I Pa. 523, 525, 5I At1. 3I0, 3II (I902); Wiltbank's Appeal, 64 $\mathrm{Pa} .256$ (I870).

I43. See cases collected supra notes I4I, I42. Contra: Restatement, Trusts, $\$ 236$ (c) and comment $w$.

I44. Accord: Restatement, Trusts, $\$ 236$ (e) and comment $y$. See also Kemble's Estate, 201 Pa. 523, 5I At1. 3I0, in which an exchange of shares of stock was treated as a mere sale, giving the life beneficiary no rights in the proceeds.

I45. McKeown's Estate, 263 Pa. 78, I06 Atl. I89 (sale for cash) ; Daily's Estate, $323 \mathrm{~Pa}$. 42, I86 Atl. 754 (exchange of shares). It makes no difference whether the trustee sells for cash or for shares of stock of the other corporation.

I46. Nirdlinger's Estate, $290 \mathrm{~Pa}$. 457, I39 At1. 200; the Restatement refused to take this step. See $\$ 236$ and comment $y$.

147. McKeown's Estate, $263 \mathrm{~Pa}$. at 86, 106 Atl. at 192; McCahan's Estate, I8 Pa. D. \& C. I7I, rev'd on other points, 3I2 $\mathrm{Pa} .515$, 168 Atl. 685.

I48. Waterhouse's Estate, $308 \mathrm{~Pa}$. at 429, I62 Atl. at 296; Nirdlinger's Estate, $290 \mathrm{~Pa}$. at $475-476$, I39 Atl. at 207 . 
burden of proof on this point, therefore, is upon the life beneficiary, ${ }^{149}$ and it is by no means an easy one.

First, he must prove the intact value of the shares, in accordance with the principles already discussed at length. This much is set aside at once as principal, but it does not follow that the balance of the proceeds will be awarded to the life beneficiary. He cannot be awarded any portion of such excess unless he can also prove that it represents earnings of the corporation, accumulated since the death of the testator. Even though the proceeds may be in excess of the intact value, they may reflect merely increased market value due to the increased earning power of the corporation, or to the expectation of dividends, or to the speculative value of the shares or the "good-will" of the corporation. Any such portion of the proceeds is principal. ${ }^{150}$ Nor is the life beneficiary entitled to the amount by which the proceeds exceed the book value of the shares at the time of sale. ${ }^{151} \mathrm{He}$ must earmark definitely the portion of the proceeds which represents earnings accumulated since the death of the testator. To the extent that this can be awarded to him without impairing the intact value, he will get it. ${ }^{152}$

In theory, it is assumed that if there are such earnings, and the proceeds are sufficient in amount to cover them, the earnings are actually reflected in the proceeds of the sale. It would be impossible for the life beneficiary to prove that the shares brought $\$ 150$ per share because of the existence of an earned surplus of $\$ 50$ per share. Last month the price might have been only \$roo per share, and if the trustee sold at that time the life beneficiary would get nothing, even though the accumulated earnings existed. Next month the price may be $\$ 200$ per share, and if the trustee sells them the life beneficiary will still get only $\$ 50$. Actually, market price has little or no relation to accumulated earnings. ${ }^{153}$ The rights of the life beneficiary, therefore, depend to a greater or less extent upon a fortuitous sale by the trustee at a time when the proceeds will be sufficient in amount to allow him to receive a portion equal to the amount of the accumulated earnings. ${ }^{154}$

It does not follow, however, that our courts are wrong in giving the life beneficiary rights which before he did not possess and which the Restate-

149. Ibid.

I50. Waterhouse's Estate, $308 \mathrm{~Pa}$. at 429, I62 Atl. at 296; Nirdlinger's Estate, $290 \mathrm{~Pa}$. at 476, 479, 139 Atl. at 207, 208.

I5I. See McKeown's Estate, $263 \mathrm{~Pa}$. at 83, I06 Atl. at I90.

I52. Waterhouse's Estate, $308 \mathrm{~Pa}$ at 429, I62 Atl. at 297; Packer's Estate (No. I), 29I $\mathrm{Pa}$ at I96-I97, I39 Atl. 867; Nirdlinger's Estate, $290 \mathrm{~Pa}$. at 475-476, I39 Atl. at 208.

I53. This is made clear by a comparison of the market prices of the shares of such standard railroads as Norfolk \& Western, during the past three or four years, with the book values of their shares, as shown by their balance sheets.

I54. Obviously, a rule which makes the rights of the life beneficiary depend on the action or inaction of others should be avoided, if possible. Yates's Estate, 28I Pa. I78, I82, I26 Atl. 254, 255 (1924). 
ment of the Law of Trusts does not now give him. ${ }^{155}$ The life beneficiary is, after all, usually the primary object of the bounty of the creator of the trust and, as such, he should be favored. ${ }^{156}$ By giving him a chance at least to recover accumulated earnings, our rule works substantial, albeit sometimes rough, justice.

\section{Termination of the Trust}

In Daily's Estate ${ }^{157}$ the Orphans' Court of Philadelphia held that the termination of the trust was a proper occasion for apportioning shares then held by the trustee in order to give the estate of the life beneficiary all earnings which the corporation had accumulated since the death of the testator but which had not been distributed. This is directly contrary to the view approved by the supreme court in Connolly's Estate (No. I), ${ }^{158}$ althoughi that case might, perhaps, be distinguished on the ground that there was no evidence upon which an apportionment could have been based.

When Daily's Estate came before the supreme court, ${ }^{159}$ that court rejected the view of the orphans' court without, however, citing the previous decision. To make it clear that the position of the court below was actually rejected, a full statement of the facts is necessary. The trust was created in I9I3, and among the assets were 200 shares of stock of an Illinois corporation. In I930 a Maryland corporation was formed as an operating company, and a Delaware corporation was formed as a holding company. In exchange for his 200 shares of the Illinois corporation, the trustee, in I930, received 800 shares of common stock and I000 shares of preferred stock of the Delaware corporation. In I934 the life beneficiary died, and the trust terminated. The court below apportioned the trustee's holdings in such a manner as to give the estate of the life beneficiary all of the accumulated earnings of this enterprise from I9I3 down to I934. The supreme court, however, held that the exchange which took place in I930 was in substance a sale or liquidation and directed an apportionment as of that date. In doing so, the estate of the life beneficiary received so much of the new shares as represented earnings accumulated from I9I 3 to I930, and the balance, namely, 503 shares of preferred and 402 shares of common stock, was awarded to the remaindermen. These latter shares, which were awarded to the remaindermen, obviously carried with them undistributed earnings accumulated by the corporation from 1930 to the death of the life bene-

I55. See supra note 146 .

I56. Opperman's Estate (No. I), 319 Pa. at 459, I79 Atl. at 732.

I57. 24 D. \& C. 628 (Orph. Ct. Phila. I935).

I58. I98 Pa. I37, 47 Atl. II25 (I90I) (recently said by the supreme court to be of doubtful authority). See Nirdlinger's Estate, $290 \mathrm{~Pa}$. at 475, I39 Atl. at 207. Accord: RESTATEMENT, TRUSTS, \$236 (e).

I59. 323 Pa. 42, I86 At1. 754 (I936). 
ficiary in I934, a period during which he was entitled to the income of the estate. It was these earnings which the court below, by treating the termination of the trust as an occasion for an apportionment, awarded to the estate of the life beneficiary, and it was this result which the supreme court disapproved. In so doing the supreme court has reaffirmed Connolly's Estate $(N o, I),{ }^{160}$ and has decided that the termination of the trust does not constitute an occasion for apportionment. Connolly's Estate (No. I) is simply an application of the older view, now discredited in this state, ${ }^{161}$ that unless there is a distribution of some kind by the corporation itself, there can be no apportionment.

Consequently, if a trustee holds shares for a long period during which the corporation accumulates large amounts of undistributed earnings, such earnings will be awarded to the life beneficiary if the trustee sells the shares, ${ }^{162}$ but if the trustee holds the shares until the termination of the trust, the life beneficiary will get nothing, and all of the undistributed earnings accumulated during the period of the trust will pass to the remaindermen. It is to be hoped that when such a case is presented to the supreme court, free from the complications present in Daily's Estate, the view of the Orphans' Court of Philadelphia will be adopted.

\section{Successive Life Beneficiaries}

The foregoing discussion concerns the rights of the life beneficiaries as a group, on the one hand, and the rights of the remaindermen on the other. A complication may arise where there are two or more successive life beneficiaries, one of whom is deceased when the occasion for apportionment arises. For example, an extraordinary dividend received after the death of the first life beneficiary may represent, in whole or in part, earnings accumulated by the corporation during the first life estate. Such a case presents a controversy between succeeding life beneficiaries.

Such a dividend is, of course, presumptively payable to the person entitled to the income of the estate at the time the dividend is declared. ${ }^{163}$ Accordingly, the estate of the first life beneficiary has the burden of proving how much of the dividend represents earnings accumulated by the corporation up to the date of his death. ${ }^{164}$ However, if this burden is sustained, the amount of such earnings will be awarded to the estate of the deceased life beneficiary. ${ }^{165}$

160. $198 \mathrm{~Pa}$. 137, 47 Atl. 1125 (Igor).

I6I. Nirdlinger's Estate, $290 \mathrm{~Pa}$. at 472, I39 Atl. at 206.

162. Nirdlinger's Estate, $290 \mathrm{~Pa} .457$, I39 Ati. 200.

I63. Graham's Estate, 296 Pa. 436, I46 At1. III (1929).

164. Graham's Estate, $296 \mathrm{~Pa}$. at 440 , I46 Atl. at II2.

I65. Neafie's Estate, 25 D. \& C. 608; Nirdlinger's Estate, 26 D. \& C. 3, I5; Simpson's Estate, 23 D. R. 27 (Orph. Ct. Phila. I9r3). Contra: Restatenent, Trusts, \$236, comment $y$. 
The same rules apply to the proceeds of a sale of shares after the death of the first life beneficiary. ${ }^{166}$ However, such proceeds are prima facie not income at all. ${ }^{167}$ Consequently, the efforts of the succeeding life beneficiary to earmark the portion which represents earnings may inure to the benefit of the estate of the first life beneficiary because, in proving that the corporation has accumulated earnings, it is impossible to avoid proving when the earnings were accumulated.

Because of the provisions of Section 22 of the Fiduciaries Act, ${ }^{168}$ ordinary dividends must be apportioned between successive life beneficiaries on a per day basis, as bond interest is apportioned. ${ }^{169}$ This is the only exception to the general rule that ordinary dividends are not apportionable at all. ${ }^{170}$ With this exception, there is no occasion for an apportionment between successive life beneficiaries except in connection with a similar apportionment between life beneficiaries on the one hand and remaindermen on the other. ${ }^{171}$

\section{The Duties of the Trustee}

A trustee, and particularly a corporate fiduciary, must use the utmost care in making allocations between income and principal, ${ }^{172}$ and he is bound by notices, given to the shareholders by the corporation, stating the source of corporate distributions. ${ }^{173}$ If he overpays the life beneficiary, the trustee will be surcharged. ${ }^{174}$

Of course, he can avoid any such risk by filing his account and having the court decide the question. Indeed, it is not only his right but also his duty to file an account for this purpose. ${ }^{175}$ Moreover, he should do so promptly, for if he carries a stock dividend as a part of principal and later it is determined that the shares should have been awarded to the life beneficiary, the trustee may be liable if, during his unreasonable delay in filing an account, the shares have depreciated. ${ }^{176}$

However, not all cases involve sums sufficient to warrant the expense of the counsel and guardian ad litem fees which would be incurred in the filing and audit of an account. In such cases the trustee cannot be blamed

I66. Neafie's Estate, 25 D. \& C. 608. Contra: Restatement, Trusts, §236, comment $y$. 167. Waterhouse's Estate, $308 \mathrm{~Pa}$. at 429, I62 Atl. at 296; Nirdlinger's Estate, $290 \mathrm{~Pa}$. at 475-476, I39 Atl. at 207.

I68. PA. Stat. AnN. (Purdon, 1930) tit. 20, §634.

169. Opperman's Estate (No. I), 319 Pa. 455, I79 Atl. 729; Given's Estate, $323 \mathrm{~Pa}$. at 46I, I85 At1. at 780 ; Thompson's Estate, 6 D. \& C. 503.

I70. See cases collected supra note 92 .

I7x. See Nirdlinger's Estate, 26 D. \& C. at I3 et seq.

I72. Opperman's Estate (No. I), 3I9 Pa. at 462, I79 At1. at 733.

173. Opperman's Estate (No. I), 319 Pa. at 463 , I79 Atl. at 734.

174. Vinton's Appeal, $99 \mathrm{~Pa} .434$.

175. Roberts's Estate, 2 D. \& C. 667 (Orph. Ct. Phila. I923).

176. See Riger's Estate, 22 D. \& C. 26I (Orph. Ct. Phila. I934), in which, however, no depreciation took place and the trustee escaped liability. 
if, instead of attempting to make an apportionment himself, he defers the questions until the next accounting.

The trustee represents both the life beneficiary and the remainderman. $\mathrm{He}$ represents one just as much as he does the other. When dealing with receipts from shares of stock, he must not take sides between the life beneficiary and remainderman. ${ }^{177}$ Accordingly, having filed his account, it would be improper for him to assume that he is the advocate of the remainderman in the resulting litigation. In such a case the trustee's only duty is to file his account with reasonable promptness and to see that all parties have due notice and an opportunity to present their claims to the court. This is not an intolerable burden. It is true that the Pennsylvania rules of apportionment are not rules of convenience, but it would seem that what inconvenience exists is cast upon the beneficiaries rather than upon the trustee.

However this may be, "it seems like a bungling rule of law that, at one time, would give what is undoubtedly income to the remaindermen, and, at another, what is as clearly capital to the life tenant". ${ }^{178}$ No such rule of law should be adopted either by the courts or by the legislature merely to make it easy for a trustee to perform duties for which he is adequately compensated.

\section{APPENDIX}

For the convenience of those who may wish to examine all the cases for themselves, the following list of cases in chronological order is suggested. It includes all important appellate decisions bearing directly upon the subject, together with the citation to the report of each case in the court below, if reported in a publication of general availability.

In Appellate Court

Given's Estate,

Daily's Estate,

Flinn's Estate,

Hostetter's Trust,

Opperman's Estate (No. I),

Flinn's Estate,

Waterhouse's Estate,

Bullitt's Estate,

Cassatt's Estate,

Chauncey's Estate,

Maris's Estate,

Baird's Estate,

Buist's Estate,
$323 \mathrm{~Pa} .456$, I85 Atl. 778 (I936) 323 Pa. 42, I86 Atl. 754 (1936) 320 Pa. I5, I8I Atl. 492 (1935)

3I9 Pa. 572, I8I At1. 567 (1935) 3I9 Pa. 455, I79 At1. 729 (I935) 310 Pa. 206, 165 Atl. 3I (1932) $308 \mathrm{~Pa} .422$, I62 At1. 295 (I932) $308 \mathrm{~Pa} .4$ 13, I62 Atl. 288 (1932) I05 Pa. Super. I4, I58 At1. 586 (I932) 303 Pa. 44I, I54 Atl. 8I4 (I93I) 3or Pa. 20, r5I Atl. 577 (1930) 299 Pa. 39, 148 Atl. 907 (1930) 297 Pa. 537, 147 At1. 606 (Ig29)

\section{In Court Below}

24 D. \& C. 628 (Orph. Ct. Phila. I935)

Reported with opinion of supreme court

I6 D. \& C. 73 (Orph. Ct. Phila. I93 I)

I6 D. \& C. 376 (Orph. Ct. Phila. 1932)

45 Montg. L. R. III (Orph. Ct. Montg. I929)

I2 D. \& C. 783 (Orph. Ct. Phila. I929)

I2 D. \& C. 575 (Orph. Ct. Phila. I929)

I2 D. \& C. I59 (Orph. Ct. Phila. I929)

177. Thompson's Estate, $262 \mathrm{~Pa}$. at 281, 105 Atl. at 274; Restatenent, Trusts, $\$ 236$, comment $a$.

I78. Vinton's Appeal, $99 \mathrm{~Pa}$. at 44I. 
Graham's Estate,

Jones v. Integrity Trust Co.,

Packer's Estate

(No. I),

Nirdlinger's Estate,

Mandeville's Estate,

Dickinson's Estate,

Mallory's Estate,

Harkness's Estate,

Wittmer's Estate,

Flaccus's Estate,

Yates's Estate,

Waterman's Estate,

Veech's Estate,

McKeown's Estate,

Thompson's Estate,

Sloan's Estate,

Willcox's Estate,

Quay's Estate,

Stokes's Estate (No. I),

Stokes's Estate (No. 2),

Boyer's Appeal, Robinson's Trust,

Kemble's Estate,

Graham's Estate,

Connolly's Estate, (No. I),

Eisner's Appeal,

Thomson's Estate,

Smith's Estate,

Oliver's Estate,

Phila. Trust, Safe

Deposit and Ins.

Co.'s Appeal,

Vinton's Appeal,

Biddle's Appeal,

Moss's Appeal,

Wiltbank's Appeal,

McKeen's Appeal,

Earp's Appeal,
In Appellate Court

$296 \mathrm{~Pa}$. 436, I46 Atl. III (I929)

292 Pa. I49, I40 Atl. 862 (Ig28)

29I Pa. I94, I39 Atl. 867 (I927)

290 Pa. 457, I39 Atl. 200 (I927)

$286 \mathrm{~Pa} .368$, 133 At1. 562 (I926)

$285 \mathrm{~Pa} .449,132$ At1. 352 (I926) $285 \mathrm{~Pa}$. I86, I3I At1. 7I4 (I926) $283 \mathrm{~Pa}$. 464, I29 Atl. 458 (I925)

283 Pa. 3II, I29 At1. 85 (I925) 283 Pa. I85, I29 Atl. 74 (I925) 28I Pa. I78, I26 Atl. 254 (I924)

279 Pa. 49I, I24 Atl. I66 (I924)

$74 \mathrm{~Pa}$. Super. 373 (r920)

$263 \mathrm{~Pa}$. 78, I06 Ati. I89 (rgrg)

262 Pa. 278, I05 At1. 273 (I9r8)

$258 \mathrm{~Pa}$. 368, I02 At1. 3I (I9I7)

$66 \mathrm{~Pa}$. Super. I82 (rgI7)

253 Pa. 80, 97 Atl. I029 (I9I6)

240 Pa. 277, 87 Atl. 97 I (I9r3)

240 Pa. 288, 87 Atl. 975 (I9I3)

224 Pa. I44, 73 Atl. 320 (Ig09)

2r8 Pa. 48I, 67 Atl. 775 (1907)

20I Pa. 523, 5I Atl. 310 (Ig02)

I98 Pa. 216, 47 Atl. I108 (Igor)

r98 Pa. I37, 47 Atl. I125 (Igor)

I75 Pa. I43, 34 Atl. 577 (I8c6)

I53 Pa. 332, 26 At1. 653 (I893)

r4o Pa. 344, 2I Atl. 438 (I89r)

I36 Pa. 43, 20 Atl. 527 (I890)

24 W. N. Cas. 137

I6 Atl. 734 (I889)

99 Pa. 434 (I882)

99 Pa. 278 (I882)

83 Pa. 264 ( 1877 )

$64 \mathrm{~Pa} .256$ (1870)

$42 \mathrm{~Pa} .479$ (1862)

$28 \mathrm{~Pa} .368$ (I857)

\section{In Court Below}

Io D. \& C. 695 (Orph. Ct. Phila. I928)

9 D. \& C. 806 (C. P. \#5, Phila. 1927)

8 D. \& C. 595 (Orph. Ct. Phila. I926)

23 Luz. L. R. 347 (Orph. Ct. Luz. 1925)

6 D. \& C. x (Orph. Ct. Phila. I925)

5 D. \& C. 333 (Orph. Ct. Erie I924)

5 D. \& C. 35 I (Orph. Ct. Phila. I924)

4 D. \& C. 569 (Orph. Ct. Phila. I924)

3 Pa. D. \& C. 442 (Orph. Ct. Phila. r923)

Reported with opinion of supreme court

$25 \mathrm{~Pa}$. D. R. 4 Io (Orph. Ct. Phila. I9I6)

Reported with opinion of supreme court

2I Pa. D. R. 425 (Orph. Ct. Phila. I9I2)

2I Pa. D. R. 425 (Orph. Ct. Phila. I9I2)

Reported with opinion of supreme court

Reported with opinion of supreme court

Reported with opinion of supreme court

Reported with opinion of supreme court

9 Pa. C. C. 639,28 W. N. Cas. $23 I$ (Orph. Ct. Phila. I89r); 30 W. N. Cas. 23 (Orph. C. Phila. I892)

Reported with opinion of supreme court; but see also $8 \mathrm{~Pa}$. C. C. 323 (Orph. Ct. Phila. I89o)

Reported with opinion of supreme court

$S u b$ nom. Turpin's Estate, 5 Co. Ct. Rep. 288 (Orph. Ct. Phila. I888)

Reported with opinion of supreme court

Sub nom. Condy's Estate, ro W. N. Cas. 3 I9 (Orph. Ct. Phila. I88I)

Reported with opinion of supreme court

7 Phila. 327 (C. P. Phila. I869)

Reported with opinion of supreme court 